\title{
ASSESSMENT OF SOIL REDISTRIBUTION AT CATCHMENT SCALE BY COUPLING A SOIL EROSION MODEL AND A SEDIMENT CONNECTIVITY INDEX (CENTRAL SPANISH PRE-PYRENEES)
}

\author{
M. LÓPEZ-VICENTE ${ }^{1, *}$, L. QUIJANO ${ }^{1}$, \\ L. PALAZÓN ${ }^{1}$, L. GASPAR ${ }^{2}$, A. NAVAS ${ }^{1}$

\begin{abstract}
${ }^{1}$ Grupo de Erosión y Evaluación de Suelo y Agua, Departamento de Suelo y Agua, Estación Experimental de Aula Dei, EEAD-CSIC, Avda. Montañana 1005, 50059 Zaragoza, Spain. ${ }^{2}$ Research Laboratory Building, University of Northern British Columbia, UNBC. Prince George, V2N 4Z9, Canadá.
\end{abstract}

\begin{abstract}
The study and quantification of soil redistribution is a complex and diffcult task and even a non-solved question at catchment scale both in field and numerical simulation studies. In this study we tackle this topic by coupling two different predicting models and a sound field-based dataset to assess the potential soil redistribution in a Mediterranean rain-fed agricultural and mountainous catchment (La Reina gully catchment, Cinco Villas region, NE Spain): the enhanced Modified-RMMF-2014 version of the "Modified Revised Morgan, Morgan and Finney" model (Morgan, 2001; LópezVicente and Navas, 2010) of soil erosion and the IC (Index of Connectivity; Borselli et al., 2008) model of sediment connectivity. In a cereal experimental plot (1.9 ha; $1 \times 1 \mathrm{~m}$ of cell size), located in the lowlands of the La Reina gully catchment, we firstly ran the IC model under six different scenarios of runoff pathways and results were compared with field observations of soil redistribution. The best performance was obtained with the IC model when the map of geomorphic features (rills, ephemeral gullies and fan deposits) was used in the simulation. Predicted rates of both models were correlated at 613 control points and three areas where identified at the plot: erosive-, stable-and depositional-prone areas, affecting 30\%, 22\% and 48\% of the soil surface, respectively. The average erosion rates in each area were 3.3, 1.5 and $1.1 \mathrm{Mg} \mathrm{ha}^{-1} \mathrm{yr}^{-1}$ with standard deviation values of 20.3, 19.0 and $8.3 \mathrm{Mg} \mathrm{ha}^{-1} \mathrm{yr}^{-1}$. Then, the IC model was run at La Reina gully catchment (231 ha; $5 \times 5 \mathrm{~m}$ ) and the IC values were analysed following the first approach. Stable areas and those mainly affected by processes of soil loss and deposition were identified. Results showed clear differences in the index of connectivity along the catchment though the extension of the areas with predominant processes of soil loss was under predicted (11\% of the catchment area). Further research should be focused on the adjustment of the IC model to catchment scale. Our approach offers a simple and alternative method to assess spatially distributed processes of soil redistribution at catchment scale that can be of interest in ungauged catchments where calibration task of numerical models is difficult to be done.
\end{abstract}


Estimación de la redistribución de suelo a escala de cuenca mediante la unión de un modelo de erosión y un índice de conectividad del sedimento (Pre-Pirineo Central español)

RESUMEN. El estudio y cuantificación de la redistribución del suelo es una tarea compleja y difícil y un asunto no resuelto a escala de cuenca, tanto en estudios de campo como mediante simulación numérica. En este trabajo abordamos este tema de investigación mediante la aplicación conjunta de dos modelos de predicción y una robusta base de datos de campo para la estimación de la redistribución potencial del suelo en una cuenca agrícola montañosa de secano de ambiente mediterráneo (cuenca del Barranco de La Reina, comarca de las Cinco Villas, NE de España): la versión "Modified-RMMF-2014" mejorada del modelo de erosión del suelo "Modified Revised Morgan, Morgan and Finney" (Morgan, 2001; LópezVicente y Navas, 2010) y el modelo IC (Index of Connectivity; Borselli et al., 2008) de conectividad del sedimento. En una parcela de cereal experimental (1.9 ha; resolución 1 x 1 m de tamaño de celda), situada en la parte baja de la cuenca del Barranco de La Reina, aplicamos el modelo IC bajo seis escenarios de escorrentía y los resultados se analizaron frente a las observaciones de campo de redistribución del suelo. La mejor simulación se obtuvo tras añadir el mapa de elementos geomorfológicos (regueros, cárcavas efímeras y abanicos de acumulación) al modelo IC. Ambos modelos se correlacionaron en 613 puntos de control y se identificaron tres áreas: pérdida neta de suelo, estable y acumulación, en el 30\%, 22\% y 48\% de la superficie de la parcela, respectivamente. Las tasas promedio de erosión en cada área fueron de 3.3, 1.5 y $1.1 \mathrm{Mg} \mathrm{ha}^{-1}$ año-1 con desviaciones típicas de 20.3, 19.0 y $8.3 \mathrm{Mg} \mathrm{ha}^{-1}$ año ${ }^{-1}$. Posteriormente, el modelo IC se aplicó en la cuenca del Barranco de La Reina (231 ha; resolución $5 \times 5 \mathrm{~m}$ ) y los valores se interpretaron en función de los resultados previos en la parcela, identificando las zonas potenciales de pérdida neta, estables y de acumulación. El modelo IC permitió identificar áreas claramente diferentes dentro de la cuenca, aunque la superficie afectada por procesos de pérdida neta se infra estimó, afectando sólo al $11 \%$ de la superficie total. Investigaciones futuras deben abordar la mejora del modelo IC a escala de cuenca. Nuestra propuesta se presenta como una alternativa sencilla para la estimación potencial de la redistribución espacial del suelo a escala de cuenca, que resulta de interés en cuencas no monitorizadas en las que la calibración de modelos numéricos resulta difícil.

Key words: soil erosion, Modified-RMMF-2014 model, index of connectivity, farmland catchment, soil redistribution.

Palabras clave: erosión del suelo, modelo Modified-RMMF-2014, índice de conectividad, cuenca agrícola, redistribución del suelo.

Received 2 December 2014 Accepted 17 February 2015

"Corresponding author: Grupo de Erosión y Evaluación de Suelo y Agua, Departamento de Suelo y Agua, Estación Experimental de Aula Dei, EEAD-CSIC, Avda. Montañana 1005, 50059 Zaragoza, Spain. E-mail: mvicente@eead.csic.es; mlopezvicente@gmail.com 


\section{Introduction}

Soil erosion by water is a widespread problem throughout the world that causes the loss of fertile soil and crop yield in agricultural areas and a reduction in the overall quality and functions of the soils (Stavi and Lal, 2011). The current world average erosion rates are a factor of 12 higher than soil sustainability, on the basis of the average rate of soil formation (Pimentel et al., 1999). In fragile and complex systems like the Mediterranean region, intense erosion processes are widespread and thus a better understanding of the processes of soil redistribution is necessary to reduce the sediment yield (García-Ruiz et al. 2013). The social and economic costs of erosion are high due to the on-site and offsite consequences (Navas et al., 2009).

Quantification of spatially distributed rates of soil redistribution (net soil loss and deposition) and sediment transfer and storage at catchment scale are non-resolved questions in soil erosion studies. The involved processes are non-linear and depend on many soil, climatic, topographic, vegetation and land use parameters and, furthermore, their effects change when considering different temporal and spatial scales (Cerdà et al., 2013). Additionally, human activities have been transforming the landscape since the first settlements, the creation of agricultural lands and the overexploitation of forests (García-Ruiz, 2010) accelerating and triggering in some places the processes of soil loss and degradation (Notebaert et al., 2011). As a consequence of these activities, numerous linear landscape elements (unpaved and paved trails, roads, land levelling, irrigation ditches, stone walls, dams, etc.) appear in landscapes, modifying the patterns of the overland flow and sediment connectivity.

Connectivity of overland flow, sediments and other solutes are currently cutting edge topics in soil erosion studies. In an attempt to advance and transfer of current understanding of this topic the Connecting European Connectivity Research "Connecteur" (http:// connecteur.info/) COST Action ES 1306 funded by the European Science Foundation started in April 2014 and will be active until April 2018. An increasing number of studies have been dealt with the role of hydrological connectivity processes within the catchment (LexartzaArtza and Wainwright, 2009), the temporal storage of runoff and run-on (Sheridan et al., 2009) and sediments (López-Vicente et al., 2013a) as well as the effect of human infrastructures (Meerkerk et al., 2009) in the accuracy of the predictions of the soil erosion models. The connectivity concept allows investigating of the effect of heterogeneities on the global behaviour of a system that contains those heterogeneities and it is an essential factor to take into account when modelling heterogeneous systems (Antoine et al., 2009).

Soil redistribution can be studied by using numerical simulation, such as Smith et al. (2014) did with the SedNet model in southern England and López-Vicente et al. (2013d, 2014b) did with the SERT model in NE Spain. Other authors obtained spatially distributed rates of net soil loss and deposition and of sediment budgets by using fallout ${ }^{137}$ Cs linked with Geographic Information System (GIS) techniques (Navas et al., 2013) and lake sediment cores (Navas et al., 2014).

Active soil erosion by water affects large parts of the soils in the Ebro River Basin (NE Spain) (e.g. Soto and Navas, 2008; Gaspar et al., 2013a, b) with high rates of soil 
loss mainly affecting the crops (ranging from almost zero to $108 \mathrm{Mg} \mathrm{ha}^{-1} \mathrm{yr}^{-1}$ ) and areas with low vegetation cover (unpaved trails, disperse scrublands) and those located in steep slopes. As a consequence the sediment loads of the Ebro River and its tributaries are very high and reservoirs retain remarkable amounts of sediments (Tena and Batalla, 2013). The Mediterranean climatic conditions and the variety of soil types explain the significant variations at temporal and spatial scales on the soil loss rates (López-Vicente et al., 2008a). The patterns and magnitude of soil delivery and redistribution in the soils of the Cinco Villas region (northern part of the Ebro River Basin) present significant variations between cultivated and non-cultivated soils (Navas and Walling, 1992).

In this study we seek to evaluate the feasibility of a novel and simple approach to map potential soil redistribution by coupling a soil erosion model with an index of sediment connectivity. An enhanced version of the Modified-RMMF (Modified Revised Morgan, Morgan and Finney; Morgan, 2001; López-Vicente and Navas, 2010) model of soil erosion and the IC (Index of Connectivity; Borselli et al., 2008) model of sediment connectivity are selected. The $R M M F$ model has been applied in many plots and catchments around the world in studies of soil erosion (e.g. Vigiak et al., 2006; Singh et al., 2007; López-Vicente et al., 2008b; Scholz et al., 2008; Fernández et al., 2010; Vieira et al., 2014). The ability of the $I C$ model to give an accurate measurement of the sediment connectivity was proved in several studies (e.g. Sougnez et al., 2011; Vigiak et al., 2012; Cavalli et al., 2013; D’Haen et al., 2013; Heckmann and Schwanghart, 2013; López-Vicente et al., 2013a). We hypothesize that the joint application of the two selected models will offer a more valuable information than the results obtained by the lonely application of each model. We firstly run both models in detail in a Mediterranean rain-fed cereal experimental plot (1.9 ha; 1 x $1 \mathrm{~m}$ of cell size). The $I C$ model is run under six scenarios of cumulative overland flow pathways and results are correlated with field data of soil redistribution. Then, the predicted rates of soil erosion with the Modified$R M M F-2014$ model are correlated with the best approach of the IC model and areas with predominant processes of soil loss, stability and deposition are identified. Finally, the weighted-IC model is run at La Reina gully catchment (186 ha; 5 x 5 m; NE Spain) and values are analysed to identify the potential stable areas and those areas mainly affected by processes of soil loss and deposition. Our approach aims to offer a simple and alternative method to map potential soil redistribution at catchment scale that can be of especial interest in ungauged catchments where calibration of numerical models is difficult to perform.

\section{Material and methods}

\subsection{The La Reina gully catchment and the experimental cereal plot}

The La Reina gully catchment is a small and open hydrological system (186 ha) that is located in the Central Spanish Pre-Pyrenees (Fig. 1a). The La Reina gully extends to the Vandunchil ephemeral stream, which is a tributary of the Castiliscar stream within the Aragón river basin in the northern part of the Ebro river basin (NE Spain). Elevation ranges between 604 and $877 \mathrm{~m}$ a.s.l. This landscape, which is located in the Cinco Villas administrative region, has a long history of human occupation, agricultural practices and 
water management. Numerous manmade infrastructures (paved and unpaved trails, rock mounds in non-cultivated areas, disperse and small settlements, shallow and long drainage ditches, stone walls, fences and vegetation strips) appear throughout the landscape and modify the natural runoff pathways and thus the hydrological and sediment connectivity (Fig. 2a). The main erosive features are areas with degraded and almost bare soils and steep slopes whereas the main depositional features are the alluvial terraces located near the gully (Fig. 1d and 2b). Rain-fed winter cereal fields occupy $28 \%$ of the catchment area, $1 \%$ is covered with unpaved and paved trails and small settlements, and the remaining $71 \%$ area is covered with natural vegetation (Mediterranean forest 33\%, scrubland 30\%, pine afforestation 7\% and meadow 1\%) (Fig. 1b). Soils are classified as Haplic Calcisols (FAO classification; Quijano et al., 2012).
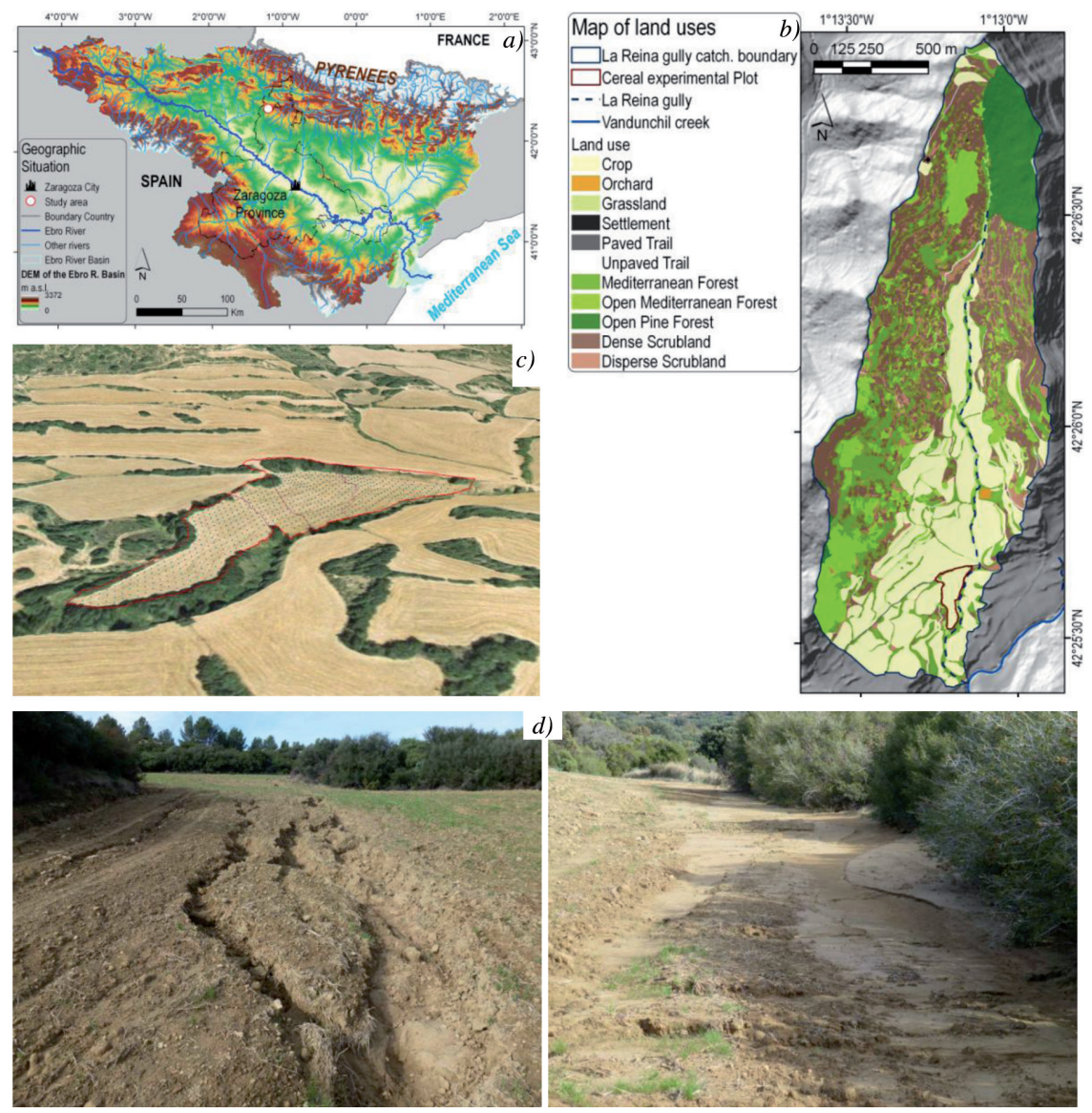

Figure 1. Location of the study area in NE Spain within the Ebro river basin (a), map of land uses of the La Reina gully catchment and location of the cereal experimental plot (b), false

$3 D$ view of the cereal experimental plot with location of the 613 soil sampling points $(c)$, and pictures showing rills and depositional fans (soil redistribution processes) developed in the same field in a steep slope (d). 

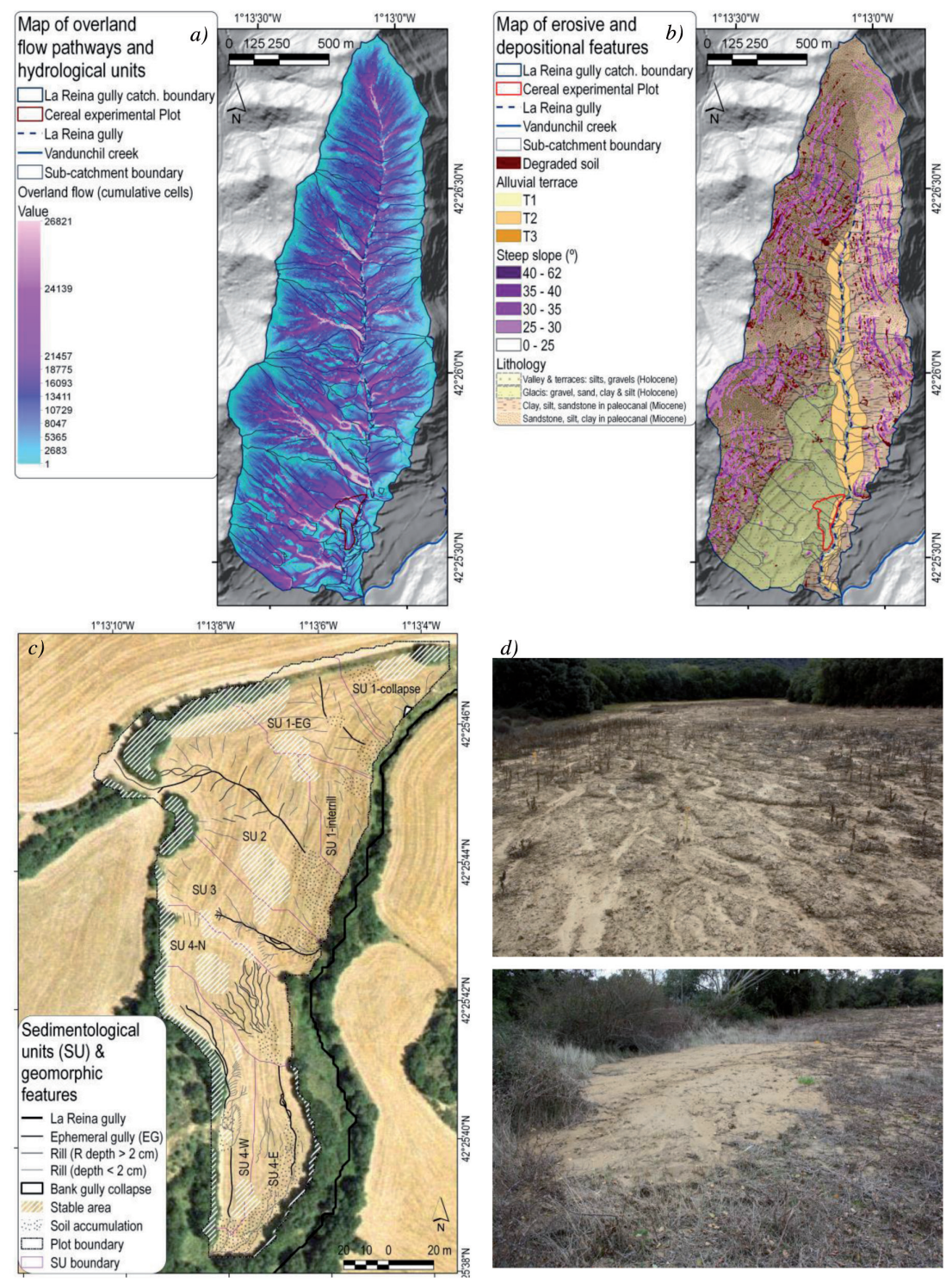

Figure 2. Map of the overland flow pathways and boundaries of the numerous hydrological units of the La Reina gully catchment (a), and map of the main erosive and depositional features of the catchment (b).

The experimental plot is a rain-fed fallow cereal field (1.6 ha) and its small upslope drainage area, known from now on in this manuscript as "the Plot". It was selected to run and test both models due to its physiographic characteristics. The Plot, that has a total extension of 1.9 ha and a mean slope steepness of $9 \%$, is located in the lower part 
of the La Reina gully catchment and it is classed as a closed-hydrological unit due to the cutting-connectivity effect of the landscape linear elements (LLEs) that surround the Plot (Quijano et al., 2013) (Fig. 1c). In previous studies four hydrological units (HU) and eight sedimentological units (SU) were identified: three HU in the northern part of the field with several outlets to the gully and one HU that covers the southern part of the field and has one outlet (López-Vicente et al., 2013c; López-Vicente et al., 2014b). Soils present low organic matter (0.4-1.6\%) and high carbonate (ca. $40 \%$ ) contents and texture is mainly silt loam (74\% of the soil surface), in some cases silty clay loam (11\%) and loam (10\%) and in some parts sandy loam and clay (Quijano et al., 2012, 2014).

The Plot is surrounded by narrow strips of dense Mediterranean vegetation, mainly holm oaks (Quercus rotundifolia and $Q$. coccifera) and dry-resistant deciduous oaks $(Q$. faginea). Patches of grass appear in the northern limit of the study area and Mediterranean shrubs (mainly Buxus sempervirens, Juniperus oxycedrus and Rosmarinus officinalis) and meadows cover the slopes between the field and the gully that appears in the eastern and southern parts. In situ field observations revealed that soil redistribution from tillage occurs, although to a lesser extent than water erosion, which is triggered by the rills and ephemeral gully systems (López-Vicente et al., 2014b) (Fig. 2c and d). The cereal field was last harvested in June 2007 and from that date onwards the field has remained fallow for research purposes. Vegetation clearance practices (chemical and mechanical weed control) were implemented to prevent scrub growth and so the soil surface has remained almost bare since that date.

The climate is continental Mediterranean with two humid periods, one in spring (Apr.-May) and a second in autumn (Sep.-Dec.) that summarizes 63\% of the total annual precipitation. Summers are usually dry with occasional thunderstorms and winters are temperate and relatively dry with few snow events. There are eleven active weather stations (WS) surrounding the study area. Of these WS we use rainfall data from the Caseda (Spanish Meteorology Agency, AEMET) and Uncastillo (Ebro river basin Water Authorities, CHEbro) WS, located $15.9 \mathrm{~km}$ north west and 10.4 south east of the Plot, respectively. A synthetic weather station WS was calculated for the period 1992-2012 (21 years) (Fig. 3). Annual potential evapotranspiration $\left(E T_{0}, \mathrm{~mm}\right)$ was calculated from the Sádaba WS (automatic system of WS of the Autonomous Community of Aragón, SARGA) located $16.8 \mathrm{~km}$ south of the Plot.
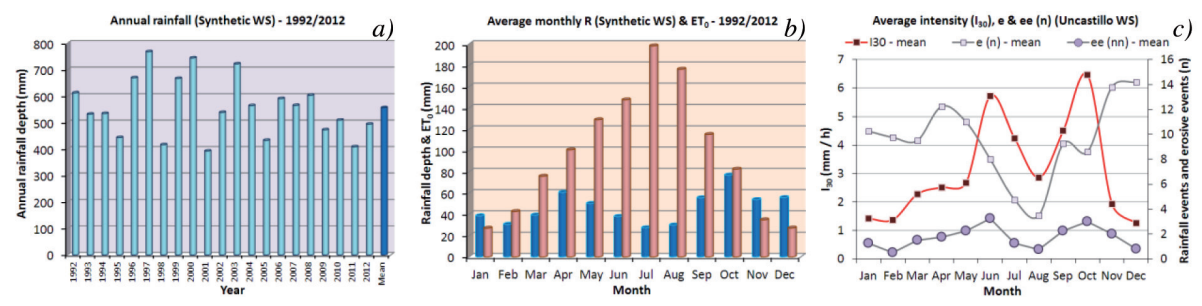

Figure 3. Annual ( a) and monthly $(b)$ rainfall depth $(R, \mathrm{~mm})$ at the synthetic weather station, and maximum rainfall intensity $(I 30, \mathrm{~mm} h-1)$, number of rainfall events $(e, n)$ and erosive events (ee, $n)$ at the Uncastillo weather station (c). 


\subsection{The Index of Connectivity (IC)}

In this study we use the index of runoff and sediment connectivity (IC) proposed by Borselli et al. (2008) as a proxy for hillslope-channel coupling and sediment delivery estimations. This index is based on topographic, land use and vegetation parameters and also computes the effect of the landscape linear elements (LLES) on the connectivity of overland flow and detached particles. The $I C$ model takes advantage of GIS techniques and accounts the characteristics of the drainage area $\left(D_{u p}\right.$, upslope module) and the flow path length that a particle has to travel to arrive at the nearest sink $\left(D_{d n}\right.$, downslope module). The $D_{d n}$ factor considers the probability that sediment arrives at a sink along a flow line whereas the $D_{u p}$ factor summarizes the potential for downward routing of the sediment produced upslope and expands the same analysis to an area:

$$
I C_{K}=\log _{10}\left(\frac{D_{u p, K}}{D_{d n, K}}\right)=\log _{10}\left(\frac{\overline{W_{K}} \cdot \overline{S_{K}} \cdot \sqrt{A_{K}}}{\sum_{i=K, n_{K}} \frac{d_{i}}{W_{i} \cdot S_{i}}}\right)
$$

where $\bar{W}$ is the average weighing factor of the upslope contributing area (dimensionless and equal to the $C$-RUSLE factor), $\bar{S}$ is the average slope gradient of the upslope contributing area $\left(\mathrm{m} \mathrm{m}^{-1}\right), A$ is the upslope contributing area $\left(\mathrm{m}^{2}\right), d_{i}$ is the length of the $i$ th cell along the downslope path $(\mathrm{m}), W_{i}$ is the weight of the $i$ th cell (dimensionless), and $S_{i}$ is the slope gradient of the $i$ th cell $\left(\mathrm{m} \mathrm{m}^{-1}\right)$. Values of slope steepness lower than 0.005 must be replaced by the value $S_{i}=0.005$ and those higher than 1 must be set to a maximum value of 1 (for more details see Cavalli et al., 2013). The subscript $K$ indicates that each cell " $i$ " has its own $I C$-value. This index is defined in the range of $[-\infty,+\infty]$ and connectivity increases when IC grows towards $+\infty$. The role of the LLES (flat and step agricultural terraces, buffer strips, ditches, pond walls, settlements, paved and unpaved trails and scarps) is added by modifying the map of flow direction: a mask with two values, 0 for the LLEs and 1 for the remaining area, is used to modify the original map of flow direction used in the flow accumulation algorithm. Connectivity changes due to changes on runoff magnitude, thus we computed different $I C$ maps with different threshold values for the "stream mask" (see Appendix A in Borselli et al., 2008). Each stream mask was associated with different geomorphic features (rills, ephemeral gullies, soil deposits, stable areas) identified in field observations and also associated with different overland flow pattern maps.

\subsection{The Modified-RMMF-2014 model of soil erosion}

In this study we ran an enhanced version, the Modified-RMMF-2014 model, of the Modified-RMMF model proposed by López-Vicente and Navas (2010) from the basis of the original Revised Morgan, Morgan and Finney (RMMF) model (Morgan, 2001). The effect of the effective volume of the soil, the processes of cumulative overland flow and the maximum surface storage capacity were added. The Modified-RMMF-2014 model 
includes two improvements: i) a water balance correction factor $(\alpha)$ so that the volume of balanced potential cumulative runoff $\left(C Q_{O B}\right)$ equal to the initial volume of available water to be accumulated in the hydrological unit; and ii) a specific factor of the runoff duration during and after the erosive rainfall event. This model estimates monthly and annual rates of soil detachment by $\operatorname{splash}\left(F, \mathrm{Mg} \mathrm{ha}^{-1}\right.$ month $\left.^{-1}\right)$ and runoff $\left(H, \mathrm{Mg} \mathrm{ha}^{-1}\right.$ month $\left.^{-1}\right)$ and compares the total rate of detachment with the runoff transport capacity $\left(T C, \mathrm{Mg} \mathrm{ha}^{-1} \mathrm{month}^{-1}\right)$ to calculate the values of soil erosion $\left(E, \mathrm{Mg} \mathrm{ha}^{-1} \mathrm{month}^{-1}\right)$ :

$$
E=\operatorname{Min}\{(F+H), \mathrm{TC}\}
$$

The detachment of a soil particle by raindrop impact or splash $\left(F, \mathrm{Mg} \mathrm{ha}^{-1} \mathrm{month}^{-1}\right)$ is computed from the total rainfall energy $\left(R E, \mathrm{~J} \mathrm{~m}^{-2}\right)$ and the parameter of soil erodibility $\left(K, \mathrm{~g} \mathrm{~J}^{-1}\right)$ :

$$
\begin{aligned}
& F=K \cdot R E \cdot 10^{-2} \\
& R E=R E(D T)+R E(L D) \\
& R E(D T)=D T \cdot K E=D T 35.9\left[1-0.5999 \exp \left(-0.034 \mathrm{I}_{m}\right)\right] \\
& R E(L D)=\left(15.9 \mathrm{PH}_{m}^{0.5}\right)-5.87
\end{aligned}
$$

where $R E(D T)\left(\mathrm{J} \mathrm{m}^{-2}\right)$ and $R E(L D)\left(\mathrm{J} \mathrm{m}^{-2}\right)$ are the kinetic energy of the direct throughfall rainfall and the kinetic energy of the leaf drainage, respectively, $D T(\mathrm{~mm})$ is the direct throughfall volume of rainfall, $K E\left(\mathrm{~J} \mathrm{~m}^{-2} \mathrm{~mm}^{-1}\right)$ is the kinetic energy of the rainfall, $I$ is the rainfall intensity $\left(\mathrm{mm} \mathrm{h}^{-1}\right)$ and $P H(\mathrm{~m})$ is the height of the plant canopy. The values of $K$ are obtained from Morgan (2001) for the different types of soil textures. When Eq. 6 yields a negative value, $E(L D)$ is assumed to be zero.

The $D T(\mathrm{~mm})$ factor is estimated from the total depth of effective rainfall $(E R, \mathrm{~mm})$ and the $E R_{m}$ is estimated from the total rainfall depth $\left(R_{m}, \mathrm{~mm}\right)$, the rainfall interception $\left(A_{m}, 0-1\right)$ and the effect of slope angle ( $S$, radians) on the quantity of rain received per unit area. The effective rainfall is split into direct throughfall, $D T$, and leaf drainage $(L D, \mathrm{~mm})$, that is intercepted by the plant canopy and reaches the ground by stemflow or dripping from leaves. The split is a direct function of the percentage canopy cover $(C C, \%)$ :

$$
\begin{aligned}
& E R_{m}=R_{m}\left(1-\mathrm{A}_{m}\right) / \cos S \\
& L D_{m}=E R_{m} \cdot C C_{m} \\
& D T_{m}=E R_{m} \cdot L D_{m}
\end{aligned}
$$

Without soil crusting neither soil repellency rainfall becomes overland flow after topsoil is saturated. The monthly initial runoff per raster cell $\left(Q_{0 m}, \mathrm{~mm}\right)$ is calculated 
assuming that runoff occurs when the mean rain per erosive rain day $\left(R_{0 m}, \mathrm{~mm}\right)$ exceeds the soil moisture storage capacity $\left(R_{c}, \mathrm{~mm}\right)$ :

$$
\begin{aligned}
Q_{0 m} & =R_{m} \cdot \exp \left(\frac{-R_{C}}{R_{\mathrm{n} m}}\right) \\
R_{C} & =1000 \cdot M S \cdot B D \cdot V o l_{e f f} \cdot E H D \cdot\left(\frac{E T_{a}}{E T_{0}}\right)^{0.5}
\end{aligned}
$$

where $M S\left(\% \mathrm{w} \mathrm{w}^{-1}\right)$ is the soil moisture content at field capacity, $B D\left(\mathrm{Mg} \mathrm{m}^{-3}\right)$ is the bulk density, $E H D(\mathrm{~m})$ is the effective hydrological depth and $E T_{a} / E T_{0}$ is the ratio between the actual and potential evapotranspiration. In this study, the effective volume of the soil, $V_{o l} l_{\text {eff }}$ (value between 0 and 1), was also considered. The effective volume is related to the volume of the soil that actually retains water and is assumed to be the same as that occupied by the soil fraction with a grain size of less than $2 \mathrm{~mm}$ (Soto and Navas, 2008). Coarse fragments play a critical role in the processes of topsoil saturation and initiation of runoff (Smets et al., 2011) and are very frequent in the Mediterranean soils. Values of EHD correspond to those included in the RMMF model (Morgan, 2001) for the different land-uses.

Once $Q_{\text {oim }}$ is calculated at each pixel " $i$ " and month " $m$ ", the maps for the whole study area are created with the Kriging interpolation method (ordinary type with constant trend removal) that provides the minimum standard error. Then, $Q_{\text {oim }}$ is routed into the digital elevation model (DEM) using a multiple flow accumulation algorithm $(M D)$ and the potential cumulative runoff, $C Q_{0 m}(\mathrm{~mm})$, is obtained. The $M D$ algorithm was chosen as the most suitable approach to describe the spatial patterns of overland flow (López-Vicente et al., 2014a). The effective runoff $\left(C Q_{\text {eff-m }}, \mathrm{mm}\right)$ is defined as the rainfall, which is neither retained on the land surface nor infiltrated into the soil and becomes overland flow until it is drained in one of the catchment channels. Values of $C Q_{\text {eff-m }}$ are computed from the potential corrected cumulative runoff $\left(C Q_{0 m B}, \mathrm{~mm}\right)$, the saturated hydraulic conductivity $\left(K_{f s}, \mathrm{~mm} \mathrm{day}^{-1}\right)$, the duration of the runoff event $(T q, \mathrm{~s})$, the number of rainfall erosive events $\left(e e_{m}, \mathrm{n}\right)$, the maximum soil surface storage capacity $\left(S S_{\text {max }-m}, \mathrm{~mm}\right)$ and the slope steepness $(S$, radian):

$$
\begin{gathered}
C Q_{e f f-m}=\left(C Q_{0 m B}-K_{f s} \cdot T q \cdot e e_{m}-S S_{\text {max-m }} \cdot e e_{m}\right) \sin S \\
C Q_{0 m B}=\alpha \cdot C Q_{0 m}=\frac{\sum_{i=1}^{i=k} E R_{i}-\sum_{i=1}^{i=k} R p_{i} \cdot e e_{m}}{\sum_{i=1}^{i=k} C Q_{0}} \cdot C Q_{0 m}
\end{gathered}
$$




$$
\begin{aligned}
& C Q_{0 m}=f\left(Q_{0 m}, \text { Acc.Algorithm }{ }_{\mathrm{MD}}, \text { LLEs, } \mathrm{DEM}_{\mathrm{resol}}\right) \\
& T q=\left(T E R-T p_{i}\right)+T q_{A f t E R}=\left(E R_{i} / e e \cdot 10 \cdot I_{m}-T p_{i}\right)+(F l L / F l V) \\
& S S_{\max -m}=0.5 \cdot R G_{m} \cdot \frac{\sin ^{2}(S I G-S)}{\sin (S I G)} \cdot \frac{\cot (S I G+S)+\cot (S I G-S)}{2 \cdot \cos (S I G) \cdot \cos (S)}
\end{aligned}
$$

where TER (s) is the total duration of the storm event, $T p$ (s) is the time to ponding of the soil surface, $T q_{A f t E R}$ (s) is the duration of overland flow after the end of the rainfall event until all runoff is infiltrated, $F l L(\mathrm{~m})$ is the flow length, $F l V\left(\mathrm{~m} \mathrm{~s}^{-1}\right)$ is the flow velocity, $R G_{m}(\mathrm{~mm})$ is the surface roughness, and $S I G$ (radians) is the surface soil and surface furrow angle. The subscript resol corresponds to the spatial resolution of the DEM because the runoff depth also depends on this parameter.

Surface roughness is the configuration of the soil caused by the randomly and the orientated (tillage practices) arrangement of soil clods. In this study the values of $R G$ proposed by Renard et al. (1997) were used for forest areas (random roughness, $R G=$ $20.3 \mathrm{~mm})$ and for cultivated fields with plough $(R G=48.3 \mathrm{~mm})$ and field cultivator $(R G$ $=17.8 \mathrm{~mm}$ ). A $S I G$ constant value of $30^{\circ}$ was used for the study area following the study of Terzoudi et al. (2007) in Greece. A correction was made to the different maps of the effective runoff for the ephemeral streams because erosion by overland flow stops as soon as the overland flow reaches the stream. To account this effect the estimated volume of runoff at the beginning of the La Reina gully is considered as the maximum runoff volume.

The $R M M F$ model estimates the detachment of soil by runoff $\left(H ; \mathrm{Mg} \mathrm{ha}^{-1} \mathrm{month}^{-1}\right)$ as a function of the runoff volume, the slope steepness and the resistance of the soil $(Z$; $\left.\mathrm{kPa}^{-1}\right)$ :

$$
\begin{aligned}
& H_{m}=Z \cdot C Q_{e f f-m}^{1.5} \cdot \sin S \cdot\left(1-G C_{m}\right) \cdot 10^{-2} \\
& Z=\frac{1}{0.5 \cdot C O H}
\end{aligned}
$$

where $G C_{m}$ (values between 0 and 1) is the percentage of ground cover and includes crop residues such as stubble, litter and rocks and $\mathrm{COH}(\mathrm{kPa})$ is the cohesion of the soil. Values of cohesion were obtained from Morgan (2001) for the different textures of the soil. Eq. 14 assumes that soil detachment by runoff only occurs where the soil is not totally protected by the ground cover. The transport capacity of runoff $\left(T C_{m}, \mathrm{Mg} \mathrm{ha}^{-1}\right.$ month $^{-1}$ ) is computed from the effective runoff volume, the slope steepness, and the $C$ and $P$ factors of the RUSLE model (Renard et al., 1997):

$$
T C_{m}=C_{m} \cdot P \cdot C Q_{e f f-m}^{2} \cdot \sin S \cdot 10^{-2}
$$




\subsection{Linking both models to estimate potential soil redistribution at catchment scale}

In a previous study in the Estaña lakes catchment (246 ha; Spanish Central PrePyrenees) López-Vicente et al. (2011) found a good correlation between the predicted values of soil erosion with the RUSLE $\left(R^{2}=0.7269\right)$ and $R M M F\left(R^{2}=0.7632\right)$ models and the values of runoff and sediment connectivity with the $I C$ model. Besides López-Vicente et al. (2013a) used the IC model to create a runoff and sediment trap effectiveness mask to improve the predictions of the Modified-RMMF model. Recently, López-Vicente et al. (2013b, c) ran the Modified-RMMF and the IC models in the experimental plot of this study by using only one approach of the "stream mask" of the $I C$ model.

\subsection{Soil sampling and input acquisition}

Soil properties and inputs were obtained in field surveys and laboratory analyses. A total of 613 soil samples were collected following a regular 5 x 5 m grid (Fig. 1c). Bulk density was calculated with the undisturbed soil cores. Samples were air-dried, ground, homogenized and quartered to pass through a $2 \mathrm{~mm}$ sieve. Soil texture, rock content and the volumetric water content at field capacity were determined for each sample. All input maps were generated from the sampling points to the Plot area with the Kriging interpolation method (ordinary type with constant trend removal). Runoff infiltration was measured at 18 representative points across the field. Values of the $C$ - and $P$-RUSLE factors and of the $K_{f s}$ for the forest, grass and the unpaved trail were obtained from López-Vicente et al. (2013d).

In this study, we used two different DEM. As the Plot size is small we preferred using a high-resolution ( $1 \times 1 \mathrm{~m}$ cell size) DEM instead of the original DEM at $5 \times 5 \mathrm{~m}$ of cell size in order to obtain a better topographic characterization. We resampled (bilinear interpolation) the original DEM-LIDAR (free available at the Spanish National Geographic Institute, IGN-Centro de Descargas) of the region $(5 \times 5 \mathrm{~m})$ by using field measurements every 5 meters in the whole field and every 1 and 3 meters in the areas with a gentle topography. At the La Reina gully catchment we used the original DEM due to its dimension. The high number of soil samples, field measurements and spatial resolution of the maps allowed a good parameterization of both models.

\section{Results and discussions}

\subsection{Lot site: Index of connectivity}

We computed six different $I C$ maps with different threshold values for the "stream mask" factor (Fig. 4): a) no stream-mask; b) automatic stream-mask starting at the beginning of the ephemeral gullies (130 cumulative pixels calculated downwards from the divide and using the overland flow pathway map and field observations (Fig. 2c and d); c) automatic stream-mask linked to the ephemeral gullies without affecting stable areas (231 pixels); d) automatic stream-mask starting at the beginning of the fans (562 pixels); e) stream-mask associated with the map of depositional areas; and 
f) stream-mask associated with the map of rills and ephemeral gullies. Although the average values of the index for the different maps are quite similar between the six approaches, ranging from -2.67 to -2.47 , the spatial patterns showed significant differences. The performance of the model predictions was assessed in relation with field characterization of stable areas and those with geomorphic features of net soil loss, delivery and deposition (Fig. 2c). The best correlation was found with the IC map derived with the stream-mask associated with the map of rills and ephemeral gullies (Fig. 4f). Cavalli et al. (2013) also found better results with the IC model when the information of the main water bodies and streams were added in the assessment of the runoff and sediment connectivity in comparison with the direct application of the $I C$ model linked to the outlets.
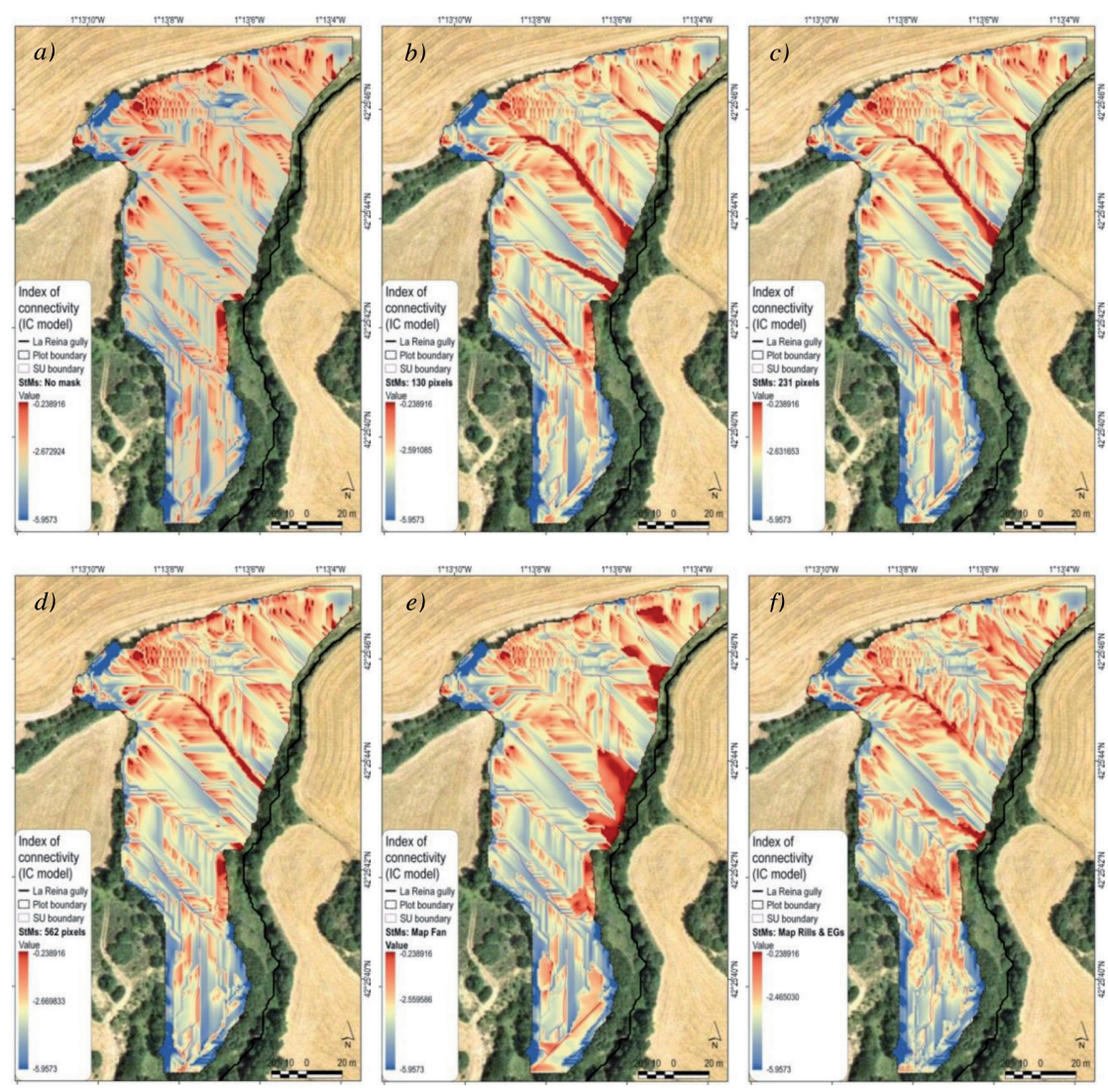

Figure 4. Runoff and sediment connectivity maps estimated with the IC model using six scenarios for the "stream mask" factor: a) no stream-mask; b) automatic stream-mask starting at the beginning of the ephemeral gullies; c) automatic stream-mask linked to the ephemeral gullies without affecting stable areas; d) automatic stream-mask starting at the beginning of the fans; $e$ ) stream-mask associated with the map of depositional areas; and f) stream-mask associated with the map of rills and ephemeral gullies. 


\subsection{Plot site: Predicted soil erosion}

The average annual rainfall depth calculated at the synthetic weather station was $556 \mathrm{~mm}$ with a strong inter-annual oscillation of 96\% (from $393 \mathrm{~mm}$ in 2001 until 768 $\mathrm{mm}$ in 1997) (Fig. 3a). The highest rainfall depth in the study area was usually recorded in October (77 mm on average) (Fig. 3b). The average annual potential evapotranspiration $\left(E T_{0}, \mathrm{~mm}\right)$ reached $1156 \mathrm{~mm}$. Rainfall events of high intensity happened in June, July, September and October, with average values of maximum rainfall intensity in $30 \mathrm{~min}$, $I_{30}$, higher than $4 \mathrm{~mm} \mathrm{~h}^{-1}$ and above $6 \mathrm{~mm} \mathrm{~h}^{-1}$ in October (Fig. 3c). Average $I_{30}$ kept below $2 \mathrm{~mm} \mathrm{~h}^{-1}$ between November and February and thus rainfall and runoff erosivity was generally low during this period.

The average annual effective runoff was $8.8 \mathrm{~mm}$ per pixel with a standard deviation value of $29.9 \mathrm{~mm}$ for the whole Plot. The maximum value of runoff reached $330.9 \mathrm{~mm}$ and the highest values appeared in some sections of the ephemeral gullies though water infiltration controlled the processes of runoff concentration and dispersion. The highest values of soil erosion appeared in October (Fig. 5a). The total amount of soil loss estimated in March, April, May, October and November add up to $78 \%$ of the total annual soil loss. A very good correlation exists with the depth of monthly rainfall (Pearson's $r=0.974$ ) and a good correlation with the number of rainy days per month (Pearson's $r=0.764$ ). However, a weak correlation was obtained with the values of monthly rainfall intensity (Pearson's $r=0.128$ ). The annual values of soil erosion correlated very well with the values of effective runoff (Pearson's $r=0.947$ ) at the soil sampling points highlighting that the processes of soil detachment and delivery by runoff were more important than the processes of soil detachment by splash. Fernández et al. (2010) also obtained in NW Spain that the transport capacity of runoff was the most limiting factor to predict soil erosion with the $R M M F$ model. The mean value of soil loss in the Plot, $1.84 \mathrm{Mg} \mathrm{ha}^{-1} \mathrm{yr}^{-1}$, is lightly above the upper limit of tolerable soil erosion that is ca. $1.4 \mathrm{Mg} \mathrm{ha}^{-1} \mathrm{yr}^{-1}$ for conditions prevalent in cultivated soils in Europe (Verheijen et al., 2009). The average soil erosion in the cultivated area, $1.4 \mathrm{Mg} \mathrm{ha}^{-1} \mathrm{yr}^{-1}$, equals the tolerable rate though the map shows a high spatial variability ( $\mathrm{sd}=7.7 \mathrm{Mg} \mathrm{ha}^{-1} \mathrm{yr}^{-1}$ ) (Fig. 5b). However, these values are lower than other rates of soil loss calculated in similar cultivated landscapes of the Spanish Pre-Pyrenees, where erosion rates average ca. $5 \mathrm{Mg} \mathrm{ha}^{-1} \mathrm{yr}^{-1}$ (Gaspar et al., 2013b; Navas et al., 2013).

The highest values of soil erosion, above $40 \mathrm{Mg} \mathrm{ha}^{-1} \mathrm{yr}^{-1}$, appeared in the concave areas (concentrated overland flow) of the ephemeral gullies and in the unpaved trail. In a previous study in the Plot López-Vicente et al. (2014b) also obtained with field measurements and modelling predictions the highest rates of soil redistribution in the ephemeral gullies. The grass and forested areas had annual rates below $0.01 \mathrm{Mg}$ $\mathrm{ha}^{-1} \mathrm{yr}^{-1}$ on average. The slope steepness $(S)$ factor does not appear to be significant and infiltration processes $\left(18<K_{f s}>481 \mathrm{~mm} \mathrm{day}^{-1}\right)$ lead the values of soil loss in the Modified-RMMF-2014 model. The paved trail had no erosion as its surface is covered with impermeable materials (asphalt). 

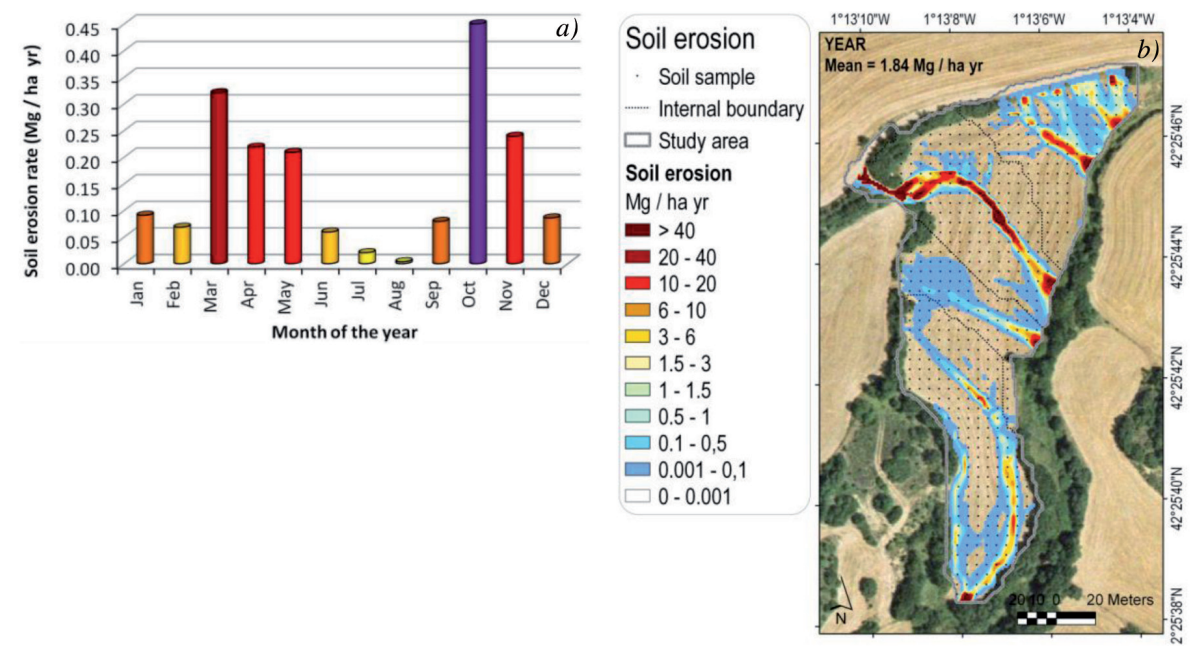

Figure 5. Monthly values of soil erosion (a) and map of annual soil erosion at the experimental cereal plot (b).

\subsection{Linking both models to estimate potential soil redistribution}

In order to link both predicting models we firstly obtained the values of the connectivity and soil erosion at each soil sampling point in the Plot. The correlation chart shows two populations related with the $I C$ values, one between -0.7 and -2.1 , and the other ranging between -2.5 and -4.1 (Fig. 6a). The first population was associated with predominant processes of soil loss and the average predicted value of soil erosion $(\bar{E})$ with the Modified-RMMF-2014 model was $3.3 \mathrm{Mg} \mathrm{ha}^{-1} \mathrm{yr}^{-1}\left(\mathrm{sd}=20.3 \mathrm{Mg} \mathrm{ha}^{-1} \mathrm{yr}^{-1}\right)$. The areas prone to erosion appeared on $30 \%$ of the total Plot surface and were mainly located in the ephemeral gullies and in the steep areas with presence of rills (Fig. 6b) (see also pictures in Fig. 2d and 6c). The second population was linked with those areas where soil deposition is the dominant process. In these areas the average predicted $\bar{E}$ was 1.1 $\mathrm{Mg} \mathrm{ha}^{-1} \mathrm{yr}^{-1}\left(\mathrm{sd}=8.3 \mathrm{Mg} \mathrm{ha}^{-1} \mathrm{yr}^{-1}\right.$ ) and appeared on $48 \%$ of the soil surface. Stable areas were predicted on the remaining $22 \%$ of the soil surface and had values of IC between -2.1 and -2.5 and the $\bar{E}$ was $1.5 \mathrm{Mg} \mathrm{ha}^{-1} \mathrm{yr}^{-1}\left(\mathrm{sd}=19.0 \mathrm{Mg} \mathrm{ha}^{-1} \mathrm{yr}^{-1}\right)$. The lowest values of connectivity and thus the highest of potential soil deposition were predicted in the divides of the Plot where the small patches of natural vegetation (mainly holm oaks) appear. Due to their topographic position these patches cannot receive soil particles from upwards and thus this prediction of the $I C$ model was wrong.

The map of sediment connectivity mirrors the spatial pattern of soil erosion though the values of $I C$ present a higher spatial variability, especially in those areas where the soil erosion model predicts both very low and very high rates. Sediment connectivity is high in the unpaved trails and those areas with concentrated overland flow. One strength of the 
IC model is its ability to identify pixels and small patches with low connectivity within areas with predominant processes of soil loss. The map of potential soil redistribution at the Plot was obtained using these threshold values and a very good correlation was found with the field-identified geomorphic features (Fig. 6c).
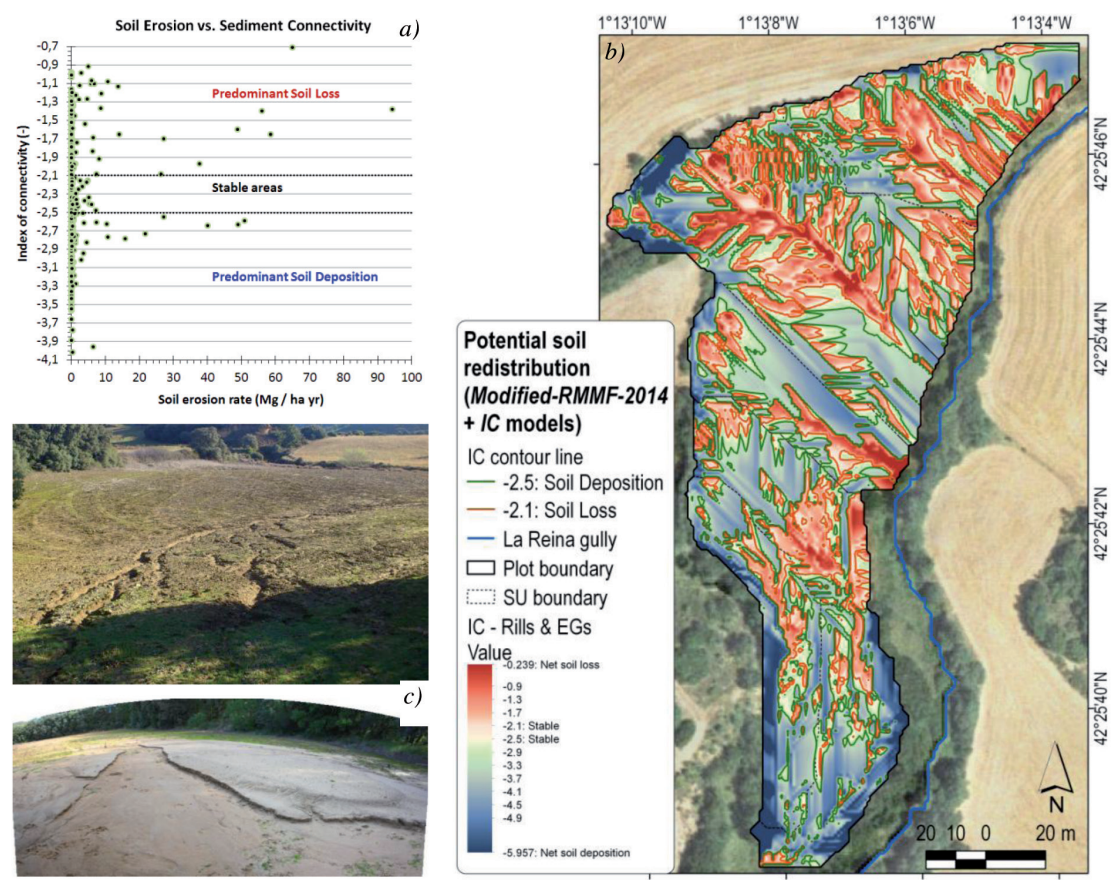

Figure 6. Correlation between the values of soil erosion and the index of connectivity (a), map of potential soil redistribution at the Plot (b) and pictures showing rills and fans in the Plot (c).

The map of runoff and sediment connectivity of the La Reina gully catchment was done following the same approach described above and the new set of $I C$ values where grouped using the identified areas of predominant soil loss and deposition at the Plot (Fig. 7). In this catchment, the $I C$ values above -4 where associated with areas where processes of soil loss are predominant. These areas appeared in only $11 \%$ of the catchment. The $I C$ values between -4.4 and -4 were associated with stable areas ( $2 \%$ of the surface) and the $I C$ values below -4.4 were associated with areas with predominant processes of soil deposition (87\% of the surface). The potential map of soil redistribution identifies different erosive areas across the catchment though the areas of net soil loss were clearly underestimated. Further research should focus on the adjustment of the IC model in the divides of the catchment where the magnitude of soil redistribution processes is lower than in the hillslopes. We also propose the application of the $I C$ model at the hydrological unit scale instead of at catchment scale. This approach should be of interest to calculate potential sediment budgets at sub-catchment scale. 


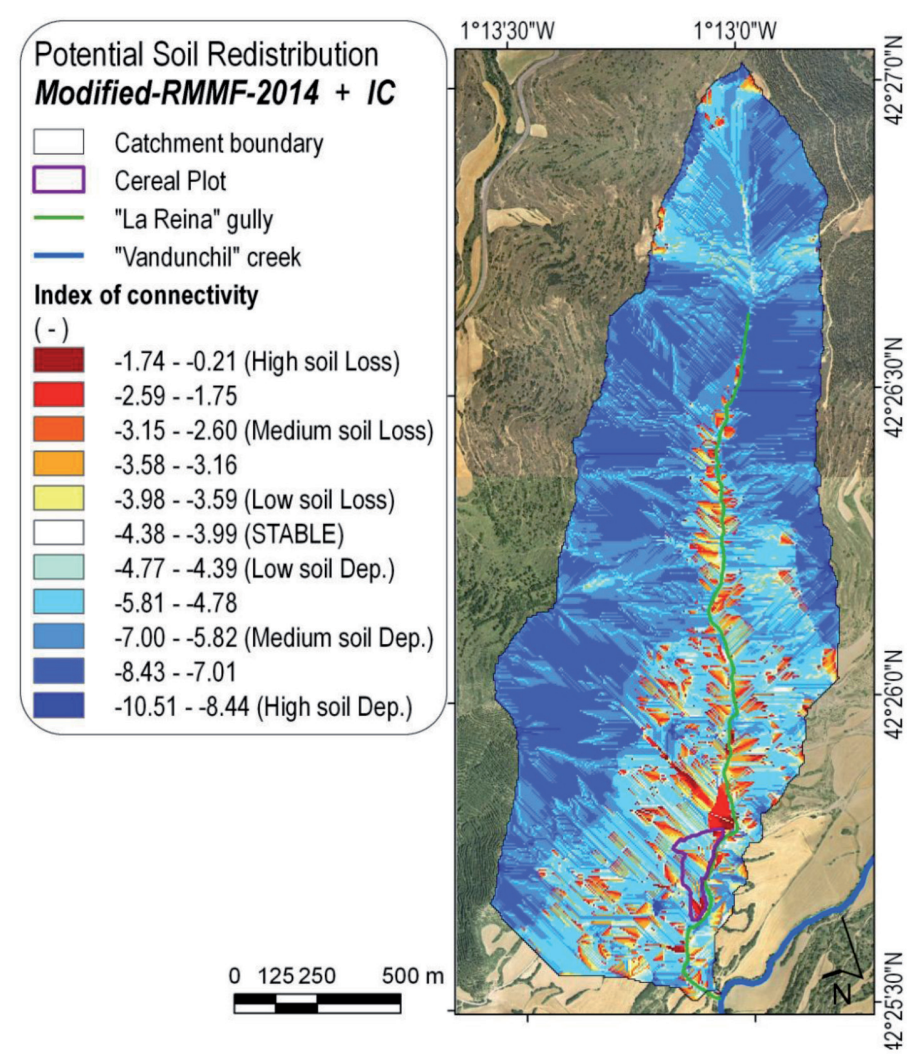

Figure 7. Runoff and sediment connectivity map estimated with the IC model at the La Reina gully catchment.

\section{Conclusions}

Six different spatial patterns of sediment connectivity were described in detail with the low-input-demanding $I C$ model. The best performance was obtained when information of the main erosive (rills and ephemeral gullies) and depositional (fan deposits) features was added. The correlation of the best $I C$ model approach with the annual predicted rates of soil erosion with the enhanced Modified-RMMF-2014 model allowed identifying those areas mainly affected by processes of net soil loss and deposition and also the stable areas. The main and standard deviation values of soil erosion in the three areas were coherent with the proposed soil redistribution categories. The average soil erosion value in the prone to erosion areas was three times higher than the average rate in the depositional areas and more than twice than the rate in the stable areas.

The combined used of the Modified-RMMF-2014 and IC models was a good choice because it made more valuable the results obtained than the results obtained with each 
model separately and help to obtain a better interpretation of the generated maps. The main shortcoming of this approach was related with the application of the IC model at catchment scale and near the divides because the stable and depositional areas cannot be discriminated well. Our approach offered a feasible simple alternative method to assess spatially distributed processes of soil redistribution at field and catchment scales that can be of especial interest in ungauged catchments where calibration of numerical models is difficult to be done or in those areas where data is limited and complex models cannot be run.

\section{Acknowledgements}

This research was funded by the Project "Erosion and redistribution of soils and nutrients in Mediterranean agro-ecosystems: radioisotopic tracers of sources and sinks and modelling of scenarios (EROMED) (CGL2011-25486/BTE)" of the Spanish Ministry of Economy and Competitiveness.

\section{References}

Antoine, M., Javaux, M., Bielders, C. 2009. What indicators can capture runoff-relevant connectivity properties of the micro-topography at the plot scale? Advances in Water Resources 32 (8), 1297-1310.

Borselli, L., Cassi, P., Torri, D. 2008. Prolegomena to sediment and flow connectivity in the landscape: A GIS and field numerical assessment. Catena 75 (3), 268-277.

Cavalli, M., Trevisani, S., Comiti, F., Marchi, L. 2013. Geomorphometric assessment of spatial sediment connectivity in small Alpine catchments. Geomorphology 188, 31-41.

Cerdà, A., Brazier, R., Nearing, M., de Vente, J. 2013. Scales and erosion. Catena 102, 1-2.

D’Haen, K., Dusar, B., Verstraeten, G., Degryse, P., De Brue, H. 2013. A sediment fingerprinting approach to understand the geomorphic coupling in an eastern Mediterranean mountainous river catchment. Geomorphology 197, 64-75.

Fernández, C., Vega, J.A., Vieira, D.C.S. 2010. Assessing soil erosion after fire and rehabilitation treatments in NW Spain: Performance of rusle and revised Morgan-Morgan-Finney models. Land Degradation \& Development 21 (1), 58-67.

García-Ruiz, J.M. 2010. The effects of land uses on soil erosion in Spain: A review. Catena 81 (1), $1-11$.

García-Ruiz, J.M., Nadal-Romero, E., Lana-Renault, N., Beguería, S. 2013. Erosion in Mediterranean landscapes: Changes and future challenges. Geomorphology 198, 20-36.

Gaspar, L., Navas, A., Machín, J., Walling, D.E. 2013a. Using ${ }^{210} \mathrm{~Pb}_{\mathrm{ex}}$ measurements to quantify soil redistribution along two complex toposequences in Mediterranean agroecosystems, northern Spain. Soil \& Tillage Research 130, 81-90.

Gaspar, L., Navas, A., Walling, D.E., Machín, J., Gómez Arozamena, J. 2013b. Using ${ }^{137} \mathrm{Cs}$ and ${ }^{210} \mathrm{~Pb}_{\mathrm{ex}}$ to assess soil redistribution on slopes at different temporal scales. Catena 102, 46-54.

Heckmann, T., Schwanghart, W. 2013. Geomorphic coupling and sediment connectivity in an alpine catchment - Exploring sediment cascades using graph theory. Geomorphology 182, 89-103.

Lexartza-Artza, I., Wainwright, J. 2009. Hydrological connectivity: Linking concepts with practical implications. Catena 79 (2), 146-152. 
López-Vicente, M., Navas, A. 2010. Routing runoff and soil particles in a distributed model with GIS: implications for soil protection in mountain agricultural landscapes. Land Degradation \& Development 21 (2), 100-109.

López-Vicente, M., Navas, A., Machín, J. 2008a. Identifying erosive periods by using RUSLE factors in mountain fields of the Central Spanish Pyrenees. Hydrology and Earth System Sciences 12 (2), 523-535.

López-Vicente, M., Navas, A., Machín, J. 2008b. Modelling soil detachment rates in rainfed agrosystems in the south-central Pyrenees. Agricultural Water Management 95 (9), 10791089.

López-Vicente, M., Navas, A., Machín, J., Gaspar, L. 2011. Spatial scale dependency of runoff and sediment connectivity in small sub-catchments in the Spanish Pyrenees. Geophysical Research Abstracts 13, EGU2011-10870-2.

López-Vicente, M., Poesen, J., Navas, A., Gaspar, L. 2013a. Predicting runoff and sediment connectivity and soil erosion by water for different land use scenarios in the Spanish PrePyrenees. Catena 102, 62-73.

López-Vicente, M., Quijano, L., Palazón, L., Machín, J., Gaspar, L., Navas, A. 2013b. Joint application of the ModRMMF and IC models of soil erosion and sediment connectivity: improvement of modelling predictions. Geophysical Research Abstracts 15, EGU20132068.

López-Vicente, M., Quijano, L., Palazón, L., Gaspar, L., Machín, J., Navas, A. 2013c. Erosión hídrica y conectividad en un Calcisol cultivado: variaciones espacio temporales de la pérdida y acumulación de suelo. In Control de la Degradación y Restauración de Suelos (VI Simposio CDRS), J.A. Sánchez Garrido, V. González Andrés, F. del Moral Torres (Eds.), Universidad de Almería, pp. 63-66.

López-Vicente, M., Navas, A., Gaspar, L., Machín, J. 2013d. Advanced modelling of runoff and soil redistribution for agricultural systems: the SERT model. Agricultural Water Management 125, 1-12.

López-Vicente, M., Pérez-Bielsa, C., López-Montero, T., Lambán, L.J., Navas, A. 2014a. Runoff simulation with eight different flow accumulation algorithms: Recommendations using a spatially distributed and open-source model. Environmental Modelling \& Software 62, 1121.

López-Vicente, M., Quijano, L., Gaspar, L., Palazón, L., Navas, A. 2014b. Severe soil erosion during a three-day exceptional rainfall event: combining modelling and field data for a fallow cereal field. Hydrological Processes DOI: 10.1002/hyp.10370.

Meerkerk, A.L., van Wesemael, B., Bellin, N. 2009. Application of connectivity theory to model the impact of terrace failure on runoff in semi-arid catchments. Hydrological Processes 23 (19), 2792-2803.

Morgan, R.P.C. 2001. A simple approach to soil loss prediction: a revised Morgan-Morgan-Finney model. Catena 44 (4), 305-322.

Morgan, R.P.C., Duzant, J.H. 2008. Modified MMF (Morgan-Morgan-Finney) model for evaluating effects of crops and vegetation cover on soil erosion. Earth Surface Processes and Landforms 33 (1), 90-106.

Navas, A., Walling, D.E. 1992. Using caesium-137 to assess sediment movement on slopes in a semiarid upland environment in Spain. In Erosion, debris flows and environment in mountain regions. Proc. International Symposium, Chengdu, China, pp. 129-138.

Navas, A., Valero-Garcés, B., Gaspar, L., Machín, J. 2009. Reconstructing the history of sediment accumulation in the Yesa reservoir: An approach for management of mountain reservoirs. Lake and Reservoir Management 25 (1), 15-27. 
Navas, A., López-Vicente, M., Gaspar, L., Machín, J. 2013. Assessing soil redistribution in a complex karst catchment using fallout ${ }^{137} \mathrm{Cs}$ and GIS. Geomorphology 196, 231-241.

Navas, A., López-Vicente, M., Gaspar, L., Palazón, L., Quijano, L. 2014. Establishing a tracer based sediment budget to preserve wetlands in Mediterranean mountain agroecosystems (NE Spain). Science of the Total Environment 496, 132-143.

Notebaert, B., Verstraeten, G., Ward, P., Renssen, H., Van Rompaey, A. 2011. Modeling the sensitivity of sediment and water runoff dynamics to Holocene climate and land use changes at the catchment scale. Geomorphology 126 (1-2), 18-31.

Pimentel, D., Skidmore, E.L., Trimble, S.W. 1999. Rates of soil erosion (multiple letters). Science 286 (5444), 1477-1478.

Quijano, L., Gaspar, L., López-Vicente, M., Machín, J., Navas, A. 2012. Indicadores de la calidad del suelo en Calcisoles mediterráneos. In Book of abstracts of the "V Congreso Ibérico de Ciencias del Suelo”, J. Pinheiro (Ed.), Azores, pp. 125.

Quijano, L., López-Vicente, M., Gaspar, L., Machín, J., Navas, A. 2013. Modelling soil redistribution in a hydrologically defined crop field with WATEM/SEDEM. Geophysical Research Abstracts 15, EGU2013-5413.

Quijano, L., Chaparro, M.A.E., Marié, D.C., Gaspar, L., Navas, A. 2014. Relevant magnetic and soil parameters as potential indicators of soil conservation status of Mediterranean agroecosystems. Geophysical Journal International 198, 1805-1817.

Renard, K.G., Foster, G.R., Weesies, G.A., McCool, D.K., Yoder, D.C. 1997. Predicting Soil Erosion by Water: A Guide to Conservation Planning with the Revised Universal Soil Loss Equation (RUSLE). Handbook \#703. US Department of Agriculture, Washington, DC.

Scholz, G., Quinton, J.N., Strauss, P. 2008. Soil erosion from sugar beet in Central Europe in response to climate change induced seasonal precipitation variations. Catena 72 (1), 91-105.

Sheridan, G.J., Jones, O.D., Lane, P.N.J. 2009. Stochastic rainfall-runoff equations for quantifying runoff and pollutant connectivity between hillslopes and streams. Geophysical Research Abstracts 11, EGU2009-3845.

Singh, K.S., Kumar, B., Khare, D., Jain, S.K. 2007. Estimation of erosion rate in a small catchment of Loktak wetland, India, using lead-210 $\left({ }^{210} \mathrm{~Pb}\right)$ technique. International Journal of Water 3 (3), 257-265.

Smets, T., López-Vicente, M., Poesen, J. 2011. Impact of subsurface rock fragments on runoff and interrill soil loss from cultivated soils. Earth Surface Processes and Landforms 36 (14), 1929-1937.

Smith, H.G., Blake, W.H., Taylor, A. 2014. Modelling particle residence times in agricultural river basins using a sediment budget model and fallout radionuclide tracers. Earth Surface Processes and Landforms, DOI: 10.1002/esp.3589.

Soto, J., Navas, A. 2008. A simple model of Cs-137 profile to estimate soil redistribution in cultivated stony soils. Radiation Measurements 43 (7), 1285-1293.

Sougnez, N., van Wesemael, B., Vanacker, V. 2011. Low erosion rates measured for steep, sparsely vegetated catchments in southeast Spain. Catena 84 (1-2), 1-11.

Stavi, I., Lal, R. 2011. Variability of soil physical quality in uneroded, eroded, and depositional cropland sites. Geomorphology 125 (1), 85-91.

Tena, A., Batalla, R.J. 2013. The sediment budget of a large river regulated by dams (The lower River Ebro, NE Spain). Journal of Soils and Sediments 13 (5), 966-980.

Terzoudi, C.B., Gemtos, T.A., Danalatos, N.G., Argyrokastritis, I. 2007. Applicability of an empirical runoff estimation method in central Greece. Soil \& Tillage Research 92 (1-2), 198-212.

Verheijen, F.G.A., Jones, R.J.A., Rickson, R.J., Smith, C.J. 2009. Tolerable versus actual soil erosion rates in Europe. Earth-Science Reviews 94 (1-4), 23-38. 
Vieira, D.C.S., Prats, S.A., Nunes, J.P., Shakesby, R.A., Coelho, C.O.A., Keizer, J.J. 2014. Modelling runoff and erosion, and their mitigation, in burned Portuguese forest using the revised Morgan-Morgan-Finney model. Forest Ecology and Management 314, 150-165.

Vigiak, O., Sterk, G., Romanowicz, R.J., Beven, K.J. 2006. A semi-empirical model to assess uncertainty of spatial patterns of erosion. Catena 66, 198-210.

Vigiak, O., Borselli, L., Newham, L.T.H., McInnes, J., Roberts, A.M. 2012. Comparison of conceptual landscape metrics to define hillslope-scale sediment delivery ratio. Geomorphology 138, 74-88. 